\title{
Twitter Investment Alerts for Ibex35 Securities
}

\author{
RAÚL GÓMEZ-MARTÍNEZ ${ }^{a}$ \\ MARÍA LUISA MEDRANO-GARCÍA \\ JOSÉ ANTONIO GALLEGO-VÁZQUEZ
}

pp. 61-71

\begin{abstract}
This paper sought to find the statistical relationship between Twitter messages and the evolution of the Spanish stocks mentioned in Tweets. We analyzed information from Twitter to evaluate stock sentiment using Stockbuzz - the first tool to gather information from the social network in Spanish. Stockbuzz has been developed by Spanish bank BBVA and shows the investors' mood for the IBEX 35 Spanish index. We use the application on investment decision making and calculate the average return depending on positive or negative Investors' Mood. We conclude that twitter is a valid tool to generate investment alerts.
\end{abstract}

KEYWORDS Twitter, social networks, investors' mood, investment alerts, stock markets.

\section{HISTORIA DEL ARTÍCULO}

¿CÓMO CITAR?:

Gómez-Martínez, R., MedranoGarcía, M.L. \& Gallego-Vázquez, J.A. (2017). Twitter Investment Alerts for Ibex35 Securities. Perspectiva Empresarial, 4(1), 61-71. http:// dx.doi.org/10.16967/rpe.v4n1a4

RECIBIDO: 14 de enero de 2017 APROBADO: 28 de febrero de 2017

CORRESPONDENCIA:

Raúl Gómez Martínez, Paseo De Artilleros, S/N, 28032, Madrid, España.

a Doctor, professor, Rey Juan Carlos University, Spain.E-mail: raul.gomez.martinez@urjc.es

$b$ Doctor, professor, Rey Juan Carlos University, Spain. E-mail: marialuisa.medrano@urjc.es

c Máster, Head of Open Innovation,BBVA, Spain.E-mail: ja.gallego.vazquez@bbva.com 


\section{¿CÓMO CITO EL ARTÍCULO? HOW TO CITE THIS PAPER?}

CHICAGO:

Gómez-Martínez, Raúl, Medrano-García, María Luisa y Gallego-Vázquez, Jose Antonio. 2017. "Twitter Investment Alerts for Ibex35 Securities". Perspectiva Empresarial 4(1): 61-71. http://dx.doi. org/10.16967/rpe.v4n1a4

MLA:

Gómez-Martínez, Raúl, Medrano-García, María Luisa y Gallego-Vázquez, Jose Antonio. "Twitter Investment Alerts for Ibex35 Securities". Perspectiva Empresarial 4.1 (2017): 61-71. Digital. http://dx.doi. org/10.16967/rpe.v4n1a4

\section{Alertas de Inversión en Twitter para Ibex35}

RESUMEN El presente artículo busca encontrar una relación estadística entre los mensajes de Twitter y la evolución de las bolsas de valores españolas que se menciona en los trinos. Analizamos información de Twitter para evaluar la percepción de la bolsa mediante Stockbuzz - la primera herramienta que recolecta información de la red social en español. Stockbuzz fue desarrollada por el banco español BBVA y muestra el ánimo de los inversores en la bolsa de valores española IBEX 35 . Utilizamos la aplicación en las decisiones de inversión hacienda y calculando el retorno promedio dependiendo del ánimo positivo o negativo de los inversores. Concluimos que Twitter es una herramienta válida para generar alertas de inversión.

PALABRAS CLAVE Twitter, redes sociales, ánimo de los inversores, alertas de inversión, bolsas de valores.

\section{Alerta de Investimento em Twitter sobre Segurança no Ibex35}

RESUMO Este artigo procurou encontrar a relação estatística entre as mensagens do Twitter e a evolução dos estoques espanhóis mencionados nos Tweets. Analisamos informações do Twitter para avaliar o sentiment do estoque usando Stockbuzz - a primeira ferramenta para coletar informações da rede social em espanhol. Stockbuzz foi desenvolvida pelo banco espanhol BBVA e mostra o clima dos investidores para o índice espanhol IBEX 35. Utilizamos o aplicativo sobre a tomada de decisões de investimento e calculamos o retorno médio dependendo da atitude positiva ou negativa dos investidores. Concluímos que Twitter é uma ferramenta válida para gerar alertas de investimento.

PALAVRAS CHAVE Twitter, redes sociais, atitude dos investidores, alertas de investimento, bolsas de valores. 


\section{Introduction}

Markowitz (1952) assumed that people making decisions in a rational way would prefer more return and less risk. However, the traditional perspective does not weigh in the influence of investors' mood and changes in their level of risk aversion. Psychological research has documented the effects of mood on decision-making process (Etzioni, 1988) and a good mood is associated with fast and efficient decision-making (Forgas, 1998).

Saunders (1993), Hirshleifer and Shumway (2003), Krivelyova and Robotti (2003), Cao and Wei (2005), Chang, Nieh, Yang, \& Yang (2006), Keef and Roush (2007), Shu and Hung (2009), and Gómez and Prado (2014) have shown empirical researches in behavioral finance that has accumulated different evidences. Said evidence shows how returns are related to mood variables. These studies argue that certain variables affect the mood or emotions of investors, thereby influencing their decisions. Consequently, asset prices and returns fluctuate with investors' mood. Hirshleifer (2001), Lucey and Dowling (2005) showed the impact of investor mood on financial markets. Cohen-Charash, Scherbaum, Kammeyer-Mueller, \& Staw (2013) showed that pleasant mood predicted increases in NASDAQ prices, while unpleasant mood predicted decreases in same. It could be concluded that collective mood is important in order to predict trends in stock prices.

In addition, we could affirm that risk attitude depends on mood status. Finucane, Alhakami, Slovic, \& Johnson (2000), Nofsinger (2005) shows that people in a good mood underestimate risk and overestimate benefit, so they are more willing to invest in risky assets than people in a bad mood are.

What factors can change investors' mood? For example, the weather. Good temperature - nice, pleasant and sunny weather - causes a good mood, but nasty weather - windy days and storms - causes a bad mood (Goldstein, 1972; Cunningham, 1979; Sanders and Brizzolara, 1982; Howarth \& Hoffman, 1984; Watson, 2000; Keller et al., 2005). The research in this area indicates that a pleasant weather puts people in a good mood and causes an optimistic atmosphere that guides investors to optimistic price stocks. Saunders (1993), Hirshleifer and Shumway (2003) found that sunshine is highly correlated with stock returns. A sunny weather is associated with optimistic investor mood, which makes investors more likely to buy stocks.

Apart from weather, there are more variables that cause mood fluctuations such as sports results, biorhythms, lunar phase or belief factors.

\section{Sports Results}

A soccer match can paralyze a country and leave the streets deserted, causing euphoria or deception in the whole population depending on the score. Edmans, García and Norli (2007) found a strong link between soccer outcomes and mood in international soccer results. They find a significant market decline after soccer losses. This loss effect is stronger in small stocks and in important games. The aforementioned authors also found a loss effect after international cricket, rugby, and basketball games. Gallagher and O’Sullivan (2011) studied the case of Ireland. They suggest that, in events of particularly high importance, losses are associated with negative returns. Gomez and Prado (2014) analyzed the effect of investor mood and soccer national team results; they did so by taking into account a sample of eight world championship holder countries. They calculated the expected return of the country's reference stock market index. After losing, the expected return is negative in all cases, with the exception of England and Uruguay. The stock market index analyzed for England is FTSE 100 (representative of United Kingdom), and which has four national contenders (England, Scotland, Wales and North Ireland); thus, it is complex to relate feelings and index. In the case of Uruguay, the sample is too little for a small market.

\section{The Lunar Cycle}

The lunar cycle affects stock prices. Yuan, Zheng and Zhu (2006) and Dichev and Janes (2003) found that stock returns are significantly lower on the days around a full moon than on the days around a new moon, and argued that the depressed mood associated with a full moon makes investors value stocks less, thereby inducing lower returns during full moon period. The explication could be simple: some studies have shown higher hormone levels during full moon phases (Cajochen et al, 2013; Coghlan, 2013). Coates and Helbert (2008) found that a trader's morning 
testosterone hormone level predicts his day's profitability. The authors showed that higher testosterone levels contribute to positive stock market results. They also found that a trader's cortisol rises with the volatility of the market and the level of risk taken

Ariel (1990), Kamstra, Kramer and Levi (2003), and Yuan et al. (2006) have found a relationship between biorhythms and mood. The so-called biorhythms are anomalies, such as the January effect, the tax loss effect, the Monday effect. It is well-known in the stock market environment, and it has been statistically proven, that September is the worst month of the year for stock markets. Moreover, crashes take place mostly in October, Monday is the worst day of the week and Friday (or the last working day of the week) is the best. Practically all positive trends in the last 100 years have occurred from November to April, and the best year of the US presidential period is the third year. The Halloween Effect, or sell in may and go away, is related to tax periods, bonuses or Christmas bonus payment.

All these effects impact stock markets due to psychological factors that affect investors' mood.

\section{Societal Beliefs}

Societal beliefs such as superstitions, horoscopes, fortune-tellers, black cats, witches and others may influence individual behavior and the stock market (Kolb \& Rodriguez, 1987; Dowling \& Lucey, 2005; Torgler, 2007). All those effects are not totally similar in findings, but studies on Friday 13th find that it is associated with below-average returns as compared with other Fridays (Kolb \& Rodriguez, 1987).

Therefore, if we conclude that investors' mood affects financial markets, the challenge that arises is how to measure mood and relate it to the market. This is a challenge faced by some authors (Darling, 1955) by using the dividends to profits ratio, or based on consumer confidence surveys (Lemmon \& Portniaguina, 2006). More recently and linked to technological development, the Internet and social networks, the relation between information about investor mood derived from the Internet and the evolution of markets has been studied. Gerow and Keane (2011) base their study on the frequency of use of different words on social networks, whilst Moat et al (2013) studied the frequency of word use in Wikipedia.
Gómez-Martínez (2013) used Internet search statistics as an indicator of the status of investor confidence or risk aversion, information with which they prepared a Risk Aversion Index (RAI), derived from the volume of Google searches on certain financial or economic terms that correlate negatively with market developments. Their article demonstrates empirically - through an econometric model - that Google search statistics provide relevant information on the evolution of financial markets and that the RAI provides predictive investment signals about the evolution of the main European stock market indexes, observing expected negative returns if the RAI increases and positive returns if not.

\section{Materials and Methods}

In this paper, we use Stockbuzz to measure Spanish Investors' Mood. Stockbuzz is a service developed by BBVA that examines how the views of investors expressed through social networks influence the actual behavior of the Spanish stock market. It is free and has open access through www.stockbuzz.es.

Stockbuzz daily prepares a "market sentiment" of the Ibex 35 shares, which is analyzed and validated in this article. It is made from the opinions of the Twitter social network for investors, experts and the general public. Everyone knows the importance of social networks in the financial world. Millions publicly discuss their experiences of different brands. In addition, both large and small investors in the financial market share their views on the main securities market and how emerging news influences their trading. And of all the social networks, Twitter is probably the most widely used for this type of analysis. However, is there any chance of analyzing the conversations about stocks in order to evaluate the sentiment?

The goal of Stockbuzz is to gather and analyze information from Twitter to evaluate stock sentiment. It is the first tool to gather this information in Spanish, and it shows the sentiment calculated for the IBEX 35 (which comprises the 35 most liquid Spanish stocks traded in the Madrid Stock Exchange General Index). These stocks include BBVA, Santander, Inditex, Telefonica and Repsol. Total capitalization for the index is around half a billion Euros.

Stockbuzz was launched on September 2012. BBVA was selected in 2013 to introduce Stockbuzz 
in one of the most important financial innovation congresses - Finnovate London 2013, in recognition for all the effort done to promote innovation in an open and collaborative model.

Stockbuzz uses 4 processes to deploy the market sentiment:

1. Stock Exchange tweet gather: Every night the Stockbuzz tool collects tweets in Spanish that have mentioned the Ibex 35 and its securities over the last 24 hours.

2. Tweets filter: An automated process that filters these tweets to eliminate irrelevant messages. It is a complicated process due to the high number of tweets about IBEX 35 companies that are not related to securities, such as the BBVA Spanish football league sponsorship, or those with non-valid words. The remaining tweets are analyzed through another automated process that rates them as positive, negative or neutral.

3. Tweet Analysis: A score is assigned, based on criteria such as user relevance and followers, large-scale trends of feeds, frequency of tweets and retweets, the public mood and Google Trends. This rating is reviewed manually by an administrator who corrects and applies further criteria to refine the information if needs be.

4. Emotional market value indicator: The last step is a statistical analysis of correlation and the predictive capacity of the sentiment indicator. Together with the criteria used by the administrator this statistical analysis feeds back into the system, thus allowing the tool to continue with its learning process.

Below are the aggregate figures of visits to the web, from its launch in September 2012 to January 2015:

- 25,458 views

- 16.656 unique users

- 41,906 page views

- Average session duration: 1.36 mins

- $34.5 \%$ repeat visitors

\section{Hypothesis and Methodology}

The objective of this study is to find the statistical relationship between the messages sent through Twitter and the evolution of the stocks that are mentioned in the Tweets. Following is the hypothesis we intend to prove:

$\mathbf{H}_{\mathbf{0}}$ : The Tweets published about Ibex 35 shares can explain the daily return of the Spanish market.

Panel data analysis is a statistical method widely used in social science and econometrics, which deals with two-dimensional (cross sectional/times series) panel data. The data are usually collected over time and over the same individuals and then a regression is run over these two dimensions.

The model we propose to test this hypothesis is inspired in the Sharpe (1964) diagonal model where the return of a share can be explained by the return of the market following the $b$ parameter. We add a new exogenous variable in this model, Investors' Mood (IM) which is the difference between positive and negative Tweets measured by Stockbuzz and the g parameter shows the relationship between this investors' mood measure and the return of that share. So we have the following model:

$$
Y i t=\alpha+\beta R_{-} I b e x_{t}+\gamma I M_{i t}+\varepsilon_{t} \quad \text { Model II }
$$

Where:

$Y_{\text {it }}$ Is the return of the stock " $\mathrm{i}$ " the day

R_Ibex $_{t}$ Is the return of Ibex 35 index a measure of the "return of the market".

$\mathrm{IM}_{\mathrm{it}}$ Is the Investors' Mood, measured as the difference between positive and negative Tweets

$\varepsilon_{\mathrm{t}}$ Is the error or disturbance term of the model.

We will accept the $\mathrm{H}_{0}$ hypothesis if the arregression coefficient is positive and different form 0 following the " $\mathrm{t}$ " stat in a $99 \%$ confidence interval.

If we accept $\mathrm{H}_{0}$, the following step is to find an application on investment decision making.

Therefore we calculate the average return depending on positive or negative Investors' Mood.

We will calculate the average return of all shares of Ibex 35 according to different levels of investors' mood. If the difference between positive and negative tweets is big, the investors' mood is clearly marked; as a consequence, we will expect bigger figures in average returns.

Thus, we define the following Investors' Mood levels IM Lx: 
- No IM When all the Tweets are neutral or/ and the number of positive tweets equals to negative tweets, so we can't find a defined Investor's Mood.

- IM L0 When the number of positive (negative) tweets is bigger than negative (positive) tweets.

- IM L1 When the difference between positive and negative tweets is bigger than 0,25 standard deviation of the daily number of tweets of the sample.

- IM L2 When the difference between positive and negative tweets is bigger than 0,5 standard deviation of the daily number of tweets of the sample.

- IM L3 When the difference between positive and negative tweets is bigger than 1 standard deviation of the daily number of tweets of the sample.

- IM L4 When the difference between positive and negative tweets is bigger than 1,5 standard deviation of the daily number of tweets of the sample.

- IM L5 When the difference between positive and negative tweets is bigger than 2 standard deviation of the daily number of tweets of the sample.

The model we propose is the following one:

$Y_{i t}=\alpha+\beta R_{-} I_{b e x_{t}}+\delta I M L_{i t}+\varepsilon_{t} \quad$ Model II

Where:

$Y_{i t}$ Is the return of the stock "i" the day " $\mathrm{t}$ "

R_Ibex $_{t}$ Is the return of Ibex 35 index a measure of the "return of the market".

$\mathrm{IML}_{\text {it }}$ Is the Investors Mood Level previously defined. The positives values will be 1 for positive IM L or -1 for negative IM $\mathrm{L}$.

$\varepsilon_{t}$ Is the error or disturbance term of the model.

We will calculate 6 different $\delta$ parameters and we could expect that, the higher the Investors'Mood level, the bigger the $\delta$ parameter. Then we face the new following hypothesis:
$\mathbf{H}_{1:}$ Investors' Mood Level can supply information of the return of the season.

$\mathbf{H}_{2}$ : The bigger the Investors' Mood Level is the information given is more accurate.

We should accept $\mathrm{H} 1$ if $\delta$ parameter is positive and significant, and we should accept $\mathrm{H} 2$ if $\mathrm{d}$ parameter calculated for level 0 or 1 is minor that $\delta$ parameters corresponding to levels 3,4 or 5 .

Investors' Mood could also anticipate the evolution of the following market session. In order to test this we will run the same regressions using one lag as Model III shows:

$Y_{i t}=\alpha+\beta R_{-} I_{\text {Ibex }}+\delta^{\prime} I M L_{i t-1}+\varepsilon t \quad$ Model III

Where:

$Y_{i t}$ Is the return of the sotck " $i$ " the day " $\mathrm{t}$ "

R_Ibex $_{t}$ Is the return of Ibex 35 index a measure of the "return of the market".

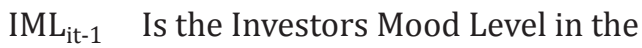
previous season.

$\varepsilon_{\mathrm{t}}$ Is the error or disturbance term of the model.

Then, the next hypothesis to test is:

$\mathbf{H}_{3}$ : Investors' Mood Level can supply information about next market session.

We should accept H3 if $\delta^{\prime}$ parameter is positive and significant.

\section{Data}

As we are focusing on the Ibex 35 we have 35 "I" individuals in our study. On the other hand we have 666 " $t$ " observations for 35 daily time series that starts on 2012, April $17^{\text {th }}$ and ends on 2014 November 21st.

The shares involved in our study are (in alphabetical order following the ticker)

$\begin{array}{ll}\text { ABE } & \text { Abertis } \\ \text { ABG } & \text { Abengoa } \\ \text { ACS } & \text { ACS } \\ \text { AMS } & \text { Amadeus } \\ \text { ANA } & \text { Acciona } \\ \text { BBVA } & \text { BBVA } \\ \text { BKIA } & \text { Bankia } \\ \text { BKT } & \text { Bankinter }\end{array}$




\begin{tabular}{|c|c|}
\hline BME & Bolsas y Mercados Españoles \\
\hline CABK & Caixabank \\
\hline DIA & DIA \\
\hline ENG & Enagas \\
\hline FCC & Fomento de Construcciones y Contratas \\
\hline FER & Ferrovial \\
\hline GAM & Gamesa \\
\hline GAS & Gas Natural \\
\hline GRF & Grifols \\
\hline IAG & International Airlines Group \\
\hline IBE & Iberdrola \\
\hline IDR & Indra \\
\hline ITX & Inditex \\
\hline JAZ & Jazztel \\
\hline MAP & Mapfre \\
\hline MTS & ArcelorMittal \\
\hline OHL & Obrascon Huarte Laín \\
\hline POP & Banco Popular \\
\hline REE & Red Eléctrica Española \\
\hline REP & Repsol \\
\hline SAB & Banco Sabadell \\
\hline SAN & Banco Santander \\
\hline SCYR & SACYR \\
\hline TEF & Telefónica \\
\hline TL5 & Mediaset Espana Comunicacion \\
\hline TRE & Técnicas Reunidas \\
\hline VIS & Viscofan \\
\hline
\end{tabular}

It is not possible to find a bigger sample because Stockbuzz started to analyze Tweets on April.

2012. Nevertheless, we consider that a model with 35 individuals ("i") and 666 observations (" $\mathrm{t}$ ") is enough for this test. Along this period, Stockbuzz has analyzed 583.098 Tweets to find the investor's mood.

Bankia is the stock with most Tweets (Figure 1); we assume so because of its polemic financial situation. Moreover, we observe that the large caps values are the ones with most Tweets. The quotes of Ibex 35 index and the 25 shares have been collected from Bloomberg.

\section{Results}

We ran the regressions for Model I using Ordinary Least Squares and Weighted Least Squares methods ${ }^{1}$. As we can see in Table 1, the results are very similar using both methods. The $\gamma$ parameter is positive and statistically a difference from 0 in a $99 \%$ significance level, so we should accept the hypothesis $\mathrm{H}_{0}$ of this study.

1 The regression has been calculated using GRETL econometric tool

FIGURE 1. Tweet analyzed

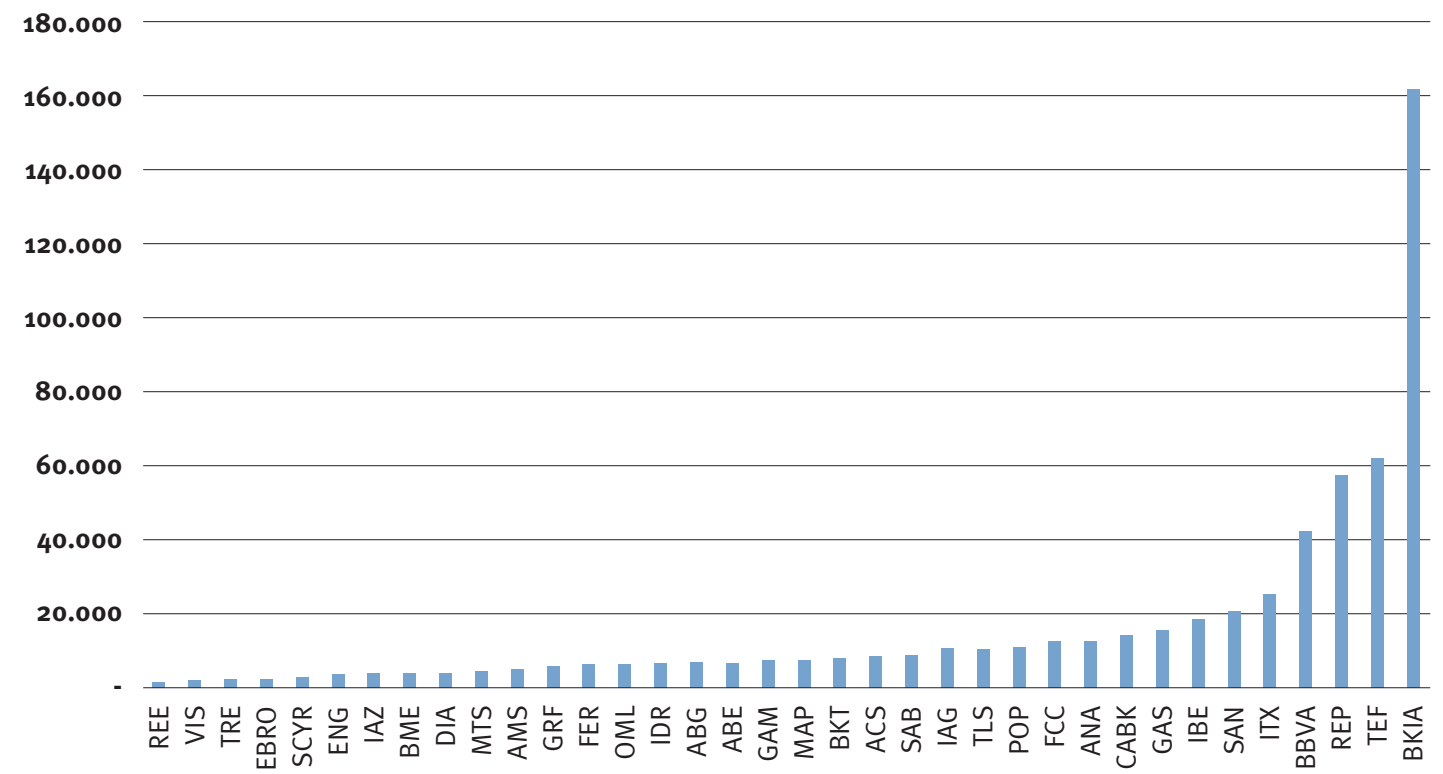


TABLE 1. Model I Regressions Results

\begin{tabular}{|c|c|c|c|c|c|c|}
\hline MODEL & PARAMETER & COEFFICIENT & DEV. EST. & T STAT & P-VALUE & SIGNIFICANCE \\
\hline \multirow{3}{*}{ OLS } & $\alpha$ & 0,02 & 0,02 & 1,18 & 0,24 & \\
\hline & $\beta$ & 0,91 & 0,01 & 82,57 & 0,00 & $\star \star \star$ \\
\hline & $\gamma$ & 0,01 & 0,00 & 21,61 & 0,00 & $\star \star \star \star$ \\
\hline \multirow{3}{*}{ WLS } & $\alpha$ & 0,00 & 0,01 & 0,35 & 0,73 & \\
\hline & $\beta$ & 0,90 & 0,01 & 139,80 & 0,00 & $\star \star \star$ \\
\hline & $\gamma$ & 0,01 & 0,00 & 18,17 & 0,00 & *** \\
\hline
\end{tabular}

SIGNIFICANCE: * $90 \%,{ }^{* \star} 95 \%$, *** $99 \%$

Source: Author based on data provided by Stockbuzz (2015).

Note. The regressions has been calculated using GRETL econometric tool.

Passed $\mathrm{H} 0$ we study the average return of the market according to Investors' Mood. As we can see in Table 2, we find 11,666 situations where the Investor Mood was positive (the number of positive tweets was bigger than negative tweets). The average return for those shares and the season is $0,5 \%$ whereas the 4,924 situations of Negative Investors' Mood mean a $-0,36 \%$ average return. $60 \%$ of the 11,666 positive Investors' Mood had a positive close, whereas $67 \%$ of the 3,282 negative Investors' Mood had a negative close.

If we repeat the same calculation for a higher level of Investors' Mood, we can see that average return is bigger as the positive Investors' Mood level is higher (except for IM L4). For negative Investors' Mood we find the same pattern; lower average return for IM L4 and IM L5 (except for IM L4). The average of positive closes in positive investors' mood levels is 65\%, and the average of negative closes for negative investors' mood levels $70 \%$.

The same study from an econometric approach (Table 3) shows a positive äparameter (99\% significance) for all the Investors' Mood levels defined, and (except for IM L4) the parameter estimated is bigger as the level is higher. Thus, Investors' Mood Level supplies information about the return of the shares and we accept H1. We should accept $\mathrm{H} 2$ despite the anomaly of IM L4, as we can see a progression of $\delta$ estimated as the level is higher.

The predictive power of Investors' Mood levels is tested through Model III. Table 4 shows the parameters estimated and we can see that $\delta^{\prime}$ parameter is positive and significant if the difference between positive and negative tweets is bigger than one standard deviation, Investors' Mood Levels 3, 4 and 5.

\section{Discussion}

Social networks have become a global mass phenomenon through which millions of people around the world express opinions and share information on topics of their interest: politics, sports, news, economy, and opinions about the performance of the securities trade market.

On the other hand, numerous studies show that investors' mood is an element that influences decisions when investing, and this mood can be affected by many factors. In addition, this mood can be measured by the messages sent through social networks.

TABLE 2. Investors' Mood Average Returns

\begin{tabular}{|c|c|c|c|c|c|c|c|c|}
\hline IM LEVEL & $\begin{array}{l}\text { POSITIVE } \\
\text { IM }\end{array}$ & $\begin{array}{l}\text { AVERAGE } \\
\text { RETURN }\end{array}$ & SUCCESS & $\%$ & $\begin{array}{l}\text { NEGATIVE } \\
\text { IM }\end{array}$ & $\begin{array}{l}\text { AVERAGE } \\
\text { RETURN }\end{array}$ & SUCCESS & $\%$ \\
\hline IM Lo & 11.666 & $0,50 \%$ & 6.959 & $60 \%$ & 4.924 & $-0,36 \%$ & 3.282 & $67 \%$ \\
\hline IM L1 & 2.113 & $0,93 \%$ & 1.411 & $67 \%$ & 907 & $-1,26 \%$ & 633 & $70 \%$ \\
\hline IM L2 & 958 & $1,12 \%$ & 626 & $65 \%$ & 540 & $-1,40 \%$ & 373 & $69 \%$ \\
\hline IM L3 & 362 & $1,12 \%$ & 231 & $64 \%$ & 277 & $-1,74 \%$ & 198 & $71 \%$ \\
\hline IM L4 & 194 & $1,05 \%$ & 122 & $63 \%$ & 194 & $-1,50 \%$ & 132 & $68 \%$ \\
\hline IM L5 & 122 & $1,25 \%$ & 80 & $66 \%$ & 150 & $-1,57 \%$ & 104 & $69 \%$ \\
\hline
\end{tabular}

Source: Author based on data provided by Stockbuzz (2015) 
TABLE 3. Model II Regressions Results

\begin{tabular}{|c|c|c|c|c|c|c|}
\hline IM LEVEL & PARAMETER & COEFFICIENT & DEV. EST. & T STAT & P-VALUE & SIGNIFICANCE: \\
\hline & $\alpha$ & $-0,12$ & 0,02 & $-7,20$ & 0,00 & $\star \star \star$ \\
\hline \multirow[t]{3}{*}{ IM Lo } & $\beta$ & 0,90 & 0,01 & 81,35 & 0,00 & $\star \star \star$ \\
\hline & $\delta$ & 0,49 & 0,02 & 25,69 & 0,00 & $* * *$ \\
\hline & $\alpha$ & $-0,02$ & 0,02 & $-1,26$ & 0,21 & \\
\hline \multirow[t]{3}{*}{ IM L1 } & $\beta$ & 0,91 & 0,01 & 82,03 & 0,00 & $\star \star \star *$ \\
\hline & $\delta$ & 0,82 & 0,04 & 19,28 & 0,00 & $\star \star \star$ \\
\hline & $\alpha$ & 0,01 & 0,02 & 0,55 & 0,58 & \\
\hline \multirow[t]{3}{*}{ IM L2 } & $\beta$ & 0,91 & 0,01 & 82,25 & 0,00 & $\star \star \star *$ \\
\hline & $\delta$ & 0,98 & 0,06 & 16,20 & 0,00 & $\star \star \star *$ \\
\hline & $\alpha$ & 0,02 & 0,02 & 1,41 & 0,16 & \\
\hline \multirow[t]{3}{*}{ IM L3 } & $\beta$ & 0,92 & 0,01 & 82,41 & 0,00 & $\star \star \star$ \\
\hline & $\delta$ & 1,13 & 0,09 & 12,22 & 0,00 & $\star \star \star *$ \\
\hline & $\alpha$ & 0,03 & 0,02 & 1,67 & 0,09 & * \\
\hline \multirow[t]{3}{*}{ IM L4 } & $\beta$ & 0,92 & 0,01 & 82,56 & 0,00 & $\star \star \star$ \\
\hline & $\delta$ & 1,10 & 0,12 & 9,25 & 0,00 & $* * *$ \\
\hline & $\alpha$ & 0,03 & 0,02 & 1,77 & 0,08 & * \\
\hline \multirow[t]{2}{*}{ IM L5 } & $\beta$ & 0,92 & 0,01 & 82,59 & 0,00 & $* * *$ \\
\hline & $\delta$ & 1,28 & 0,14 & 9,00 & 0,00 & $\star \star \star$ \\
\hline
\end{tabular}

SIGNIFICANCE: * $90 \%,{ }^{* \star} 95 \%,{ }^{* \star *} 99 \%$

Source: Authors based on data provided by Stockbuzz (2015).

TABLE 4. Model III Regressions Results

\begin{tabular}{|c|c|c|c|c|c|c|}
\hline IM LEVEL & PARAMETER & COEFFICIENT & DESV EST. & T STAT & P-VALUE & SIGNIFICANCE \\
\hline \multirow{3}{*}{ IM Lo } & $\alpha$ & 0,03 & 0,02 & 1,84 & 0,0657 & * \\
\hline & $\beta$ & 0,92 & 0,01 & 82,45 & 0 & $\star \star \star *$ \\
\hline & $\delta^{\prime}$ & $-0,02$ & 0,02 & $-0,84$ & 0,4014 & \\
\hline \multirow{3}{*}{ IM L1 } & $\alpha$ & 0,03 & 0,02 & 1,88 & 0,0598 & * \\
\hline & $\beta$ & 0,92 & 0,01 & 82,46 & 0 & $\star \star \star$ \\
\hline & $\delta^{\prime}$ & $-0,07$ & 0,04 & $-1,63$ & 0,1037 & \\
\hline \multirow{3}{*}{ IM L2 } & $\alpha$ & 0,03 & 0,02 & 1,73 & 0,084 & * \\
\hline & $\beta$ & 0,92 & 0,01 & 82,45 & 0 & $\star \star \star *$ \\
\hline & $\delta^{\prime}$ & $-0,07$ & 0,06 & $-1,12$ & 0,2622 & \\
\hline \multirow{3}{*}{ IM L3 } & $\alpha$ & 0,02 & 0,02 & 1,60 & 0,1089 & \\
\hline & $\beta$ & 0,92 & 0,01 & 82,47 & 0 & $* \star *$ \\
\hline & $\delta^{\prime}$ & 0,21 & 0,09 & 2,27 & 0,0235 & ** \\
\hline \multirow{3}{*}{ IM L4 } & $\alpha$ & 0,03 & 0,02 & 1,66 & 0,098 & * \\
\hline & $\beta$ & 0,92 & 0,01 & 82,46 & 0 & $\star \star *$ \\
\hline & $\delta^{\prime}$ & 0,38 & 0,12 & 3,19 & 0,0014 & $\star \star \star *$ \\
\hline \multirow{3}{*}{ IM L5 } & $\alpha$ & 0,03 & 0,02 & 1,67 & 0,0943 & * \\
\hline & $\beta$ & 0,92 & 0,01 & 82,45 & 0 & $\star \star \star$ \\
\hline & $\delta^{\prime}$ & 0,25 & 0,14 & 1,78 & 0,0749 & * \\
\hline
\end{tabular}

SIGNIFICANCE: * $90 \%,{ }^{* *} 95 \%,{ }^{\star \star *} 99 \%$

Source: Author based on data provided by Stockbuzz (2015) 
Our study shows that Investors' Mood - as measured through Stockbuzz - is a powerful variable in order to understand and predict the evolution of stock market. The econometrics models shows that Investors' Mood variables are significant at al 99\% confidence level. Our econometric model measures the effect of each positive or negative tweet in one basic point over or below the daily market return.

Moving forward, investment alerts generated through Twitter Investors' Mood are a useful information source for short-term investors. The stronger the alert, the more relevant the signal for investors, as shown in the results of Models II and III.

The aim of Stockbuzz is to use the social network Twitter to identify any tweets pouring an opinion on the behavior of a given value of the IBEX 35. This is technically a very complex task, given the large number of tweets written on a daily basis. Furthermore, we can quantify these tweets as being positive, negative and neutral, in order to create a "market sentiment index".

This study analyzes the sentiment index of the market on Stockbuzz since its launch in 2012, and shows a clear correlation between this investor sentiment and the actual market behavior.

This empirical testing is an incentive to work in the analysis of social networks as a support tool for the investor. Particularly, this study supports the method proposed by Stockbuzz and opens new pathways for growth.

\section{REFERENCES}

Ariel, R. A. (1990). High stock returns before holidays: existence and evidence on possible causes. Journal of Finance, 45, 1611-1626.

Cajochen, C., Altanay-Ekici, S., Münch, M., Frey, S., Knoblauch, V., \& Wirz-Justice, A. (2013). Evidence that the lunar cycle influences human sleep. Current Biology, 23(15), 1485-1488.

Cao, M., \& Wei, J. (2005). Stock market returns: a note on temperature anomaly. Journal of Banking \& Finance, 29, 1559-1573.

Chang, T., Nieh, C. C., Yang, M. J., \& Yang, T. Y. (2006). Are stock market returns related to the weather effects? Empirical evidence from Taiwan. Physica A, 364, 343-354.

Coates, J. M., \& Herbert, J. (2008). Endogenous steroids and financial risk taking on a London Trading floor. Proceedings of the National Academy of
Sciences of the United States of America, 105(16), 6167-6172.

Coghlan, A. (2013). Full moon could be to blame for a poor night's sleep. New Scientist, 219(2928), 12. doi:http://dx.doi.org/10.1016/S02624079(13)61911-9.

Cohen-Charash, Y., Scherbaum, C. A., Kammeyer-Mueller, J. D., \& Staw, B. M. (2013). Mood and the market: Can press reports of investors' mood predict stock prices?. PLOS ONE, 8(8), e72031. doi:10.1371/journal.pone.0072031.

Cunningham, M. R. (1979). Weather, mood and helping behaviour: quasi-experiment with the sunshine Samaritan. Journal of Personality and Social Psychology, 37, 1947-1956.

Darling, P. G. (1955). A surrogative measure of business confidence and its relation to stock prices. The Journal of Finance, 10(4), 442-458.

Dichev, I. D., \& Janes, T. D. (2003). Lunar cycle effects in stock returns. Journal of Private Equity, 6(4), 8-29.

Dowling, M., \& Lucey, B. M. (2005). Weather, biorhythms, beliefs and stock returns - some preliminary Irish evidence. International Review of Financial Analysis, 14, 337-355.

Edmans, A., García, D., \& Norli, O. (2007). Sports sentiment and stock returns. The Journal of Finance, 62(4), 1967-1998.

Finucane, M. L., Alhakami, A., Slovic, P., \& Johnson, S. M. (2000). The affect heuristic in judgments of risks and benefits. Journal of Behavioural Decision Making, 13, 1-17.

Forgas, J. P. (1998). On being happy and mistaken: mood effects on the fundamental attribution error. Journal of Personality and Social Psychology, 75, 318-331.

Gallagher, R., \& O’Sullivan, N. (2011). Asset price effects arising from sports results and investor mood: The case of a homogenous fan base area. Applied Economics Quarterly, 57(4), 285-301.

Gerow, A., \& Keane, M. T. (2011). Mining the Web for the voice of the herd to spot stock market bubbles. Paper presented at the International Joint Conference of Artificial Inteligence. Barcelona, España.

Goldstein, K. M. (1972). Weather, mood, and internalexternal control. Perceptual Motor Skills, 35, 786.

Gómez, R. (2013). Señales de inversión basadas en un índice de aversión al riesgo. Investigaciones Europeas de Dirección y Economía de la Empresa, (0), http://dx.doi.org/10.1016/j.iedee.2012.12.001.

Gómez, R., \& Prado, C. (2014). Sentimiento del inversor, selecciones nacionales de fútbol y su influencia sobre sus índices nacionales. Revista Europea de Dirección y Economía de la Empresa, 23(3), 99-114.

Hirshleifer, D., \& Shumway, T. (2003). Good day sunshine: stock returns and the weather. The Journal of Finance, 58(3), 1009-1032. 
Howarth, E., \& Hoffman, M. S., (1984). A multidimensional approach to the relationship between mood and weather. British Journal of Psychology, 75, 15-23.

Kamstra, M., Kramer, L. A., \& Levi, M. D. (2003). Winter blues: Seasonal Affective Disorder (SAD) and stock market returns. American Economic Review, 93(1), 324-343.

Keef, S. P., \& Roush, M. L. (2007). Daily weather effects on the returns of Australian stock indices. Applied Financial Economics, 17, 173-184.

Keller, M.C., Fredrickson, B.L., Ybarra, O., Côté, S., Johnson, K., Mikels, J., Conway, A., \& Wager, T. (2005) A warm heart and a clear head, Psychological Science, 16, 724-731.

Kolb, R. W., \& Rodriguez, R. J. (1987). Friday the thirteenth: Part VII - A note. Journal of Finance, 42(5), 1385-1387.

Krivelyova, A., \& Robotti, C. (2003). Playing the field: geomagnetic storms and international stock markets. Working paper 2003-5, Federal Reserve Bank of Atlanta.

Lemmon, M., \& Portniguina, E. (2006). Consumer confidence and asset prices: Some empirical evidence. The Review of Financial Studies, 19(4), 1499-1529.

Lucey, B. M., \& Dowling, M. (2005). The role of feelings in investor decision-making. Journal of economic surveys, 19, 211-237.
Markowitz, H. (1952). Portfolio selection. The Journal of Finance, 7, 77-91.

Moat, H., Curme, C., Avakian, A., Kenett, D. Y., Stanley, H. E., \& Resi, T. (2013). Quantifying Wikipedia Usage Patterns Before Stock Market Moves. Scientific Reports, 3, 1-5.

Nofsinger, J. R. 2005. Social mood and financial economics. The Journal of Behavioral Finance, 6, 144-160.

Sanders, J. L., \& Brizzolara, M. S. (1982). Relationships between mood and weather. Journal of General Psychology, 107, 157-158.

Saunders Jr., E. M. (1993). Stock prices and Wall Street weather. The American Economic Review, 83, 1337-1345.

Shu, H. C. 2010. Investor mood and financial Markets. Journal of Economic Behavior \& Organization, 76, 267-282.

Shu, H. C., \& Hung, M. W. (2009). Effect of wind on stock market returns: Evidence from European markets. Applied Financial Economics, 19, 893-904.

Stockbuzz. 2015. www.stockbuzz.com.

Torgler, B. (2007). Determinants of superstition. Journal of Socio-Economics, 36(5), 713-733.

Yuan, K., Zheng, L., \& Zhu, Q. (2006). Are investors moonstruck? Lunar phases and stock returns. Journal of Empirical Finance, 13(1), 1-23. 
